\title{
Influence of Some Cultural Practices on the Incidence and Severity of Leaf Spot Disease of Telfairia occidentalis in Dschang
}

\author{
Kpu Andrew Kebei*, Mbong Grace Annih, Agyingi Lucy Ambang \\ Department of Plant Biology, Faculty of Science, University of Dschang, Dschang, Cameroon \\ Email: *andrewkebei@yahoo.com
}

How to cite this paper: Kebei, K.A., Annih, M.G. and Ambang, A.L. (2020) Influence of Some Cultural Practices on the Incidence and Severity of Leaf Spot Disease of Telfairia occidentalis in Dschang. American Journal of Plant Sciences, 11, 1861-1877. https://doi.org/10.4236/ajps.2020.1112133

Received: August 10, 2020

Accepted: December 1, 2020

Published: December 4, 2020

Copyright ( 2020 by author(s) and Scientific Research Publishing Inc. This work is licensed under the Creative Commons Attribution International License (CC BY 4.0).

http://creativecommons.org/licenses/by/4.0/

\begin{abstract}
Fungi diseases are major diseases of Telfairia occidentalis (fluted pumpkin) in the major growing areas of the crop in Cameroon. This study was conducted between March and June in the cropping seasons of 2019 and 2020 to determine the effect of some cultural strategies viz.: tillage and no till, variation of sowing date and removal of diseased leaves on the incidence and severity of leaf spot disease caused by Phoma sorghina. There were four sowing dates, and two tillage systems with no variation in planting distance in the two cropping seasons. The design used was Randomized Complete Block Design (RCBD) with three replications. There were three plots for each sowing date within each replication. Seeds were sown at the rate of $1 \mathrm{~m} \times 1 \mathrm{~m}$, with four seeds per experimental unit. Data for disease incidence and severity was recorded every fortnight, commencing three weeks after emergence (WAE) and for a period of eight weeks for each sowing date. Disease incidence and severity was determined using Microsoft Excel 2010 and the data was subjected to statistical analysis and the means separated by Duncan Multiple Range Test (DMRT) at $95 \%$ confidence interval. In addition, the relationship between disease incidence and disease severity was also determined using Pearson correlation. Analysis of variance showed that there was no significant difference in leaf spot disease incidence at till and no-till units within this study period irrespective of sowing date. However, significant differences in leaf spot disease incidence and severity was recorded between the two cropping seasons. Sowing date four recorded the highest disease severity $(1.611 \pm 0.73)$ compared to sowing date two and three which was significant but comparable to sowing date one. The lowest disease severity $(1.257 \pm 0.697)$ was documented at sowing date two compared to sowing date one and four but comparable to sowing date three. Pearson correlation analysis revealed that there was a significant positive correlation $(+0.560)$ between leaf spot disease incidence and severity which was statistically significant at $\alpha=0.01(\mathrm{p}<0.01)$. In
\end{abstract}


order to enhance production of Telfairia occidentalis leaves with reduced disease incidence and severity, sowing dates two and three (first and second weeks of April respectively) coupled with removal of disease leaves every fortnight could regardless of tillage systems well manage leaf spot disease compared to sowing dates one and four.

\section{Keywords}

Telfairia occidentalis, Cultural Practices, Incidence, Severity

\section{Introduction}

Telfairia occidentalis Hook. f. is a perennial vine of the cucurbit family [1] with no secondary growth. The plant is commonly known in Cameroon for its highly prized dark green leaves. Due to its high nutritional value leaves are often prepared as an important delicacy in several households and cuisines. The leaves are a reservoir of novel compounds, minerals, and vitamins with important advantages for human health and body development [2]. This leafy vegetable is also used as a food supplement [3].

Despite the immense economic importance of the vegetable to the rural population of Cameroon the nutritional, health benefits to the human population and livestock, the sustained production of the crop still remains a great challenge due to poor soils, drought, insect pest and disease. The diseases are more often fungal attacks and varying symptoms amongst which are generally: powdery mildew, soft rot, mottling, stunting and chlorosis [4]. The fungus, Phoma sorghina, a ubiquitous facultative phytopathogen [5] attacks the leaves of the crop and produces localized lesions of dead or collapsed cells with the effect of reducing the leaf lamina. This has the effect of minimizing production of the leafy vegetable and degrades its quality. Infection of leaves by the pathogen significantly reduces the nutrient content [6]. Phoma sorghina is increasingly becoming an important food crop pathogen, also involved with food contamination in bananas and cereals [5].

[7] reported that leaf spot disease of Telfairia occidentalis can be managed by spraying with chemicals every fortnight. However, chemical control of plant diseases is of potential danger to man, non-target beneficial organisms and the environment [8] and can also result in residual chemicals in food [9]. Given the fact that the use of chemicals cannot be precluded as a method for disease control, the cost of these chemicals and their long term effects or consequences on the natural ecosystem [10] expertise [8] and high cost require that other control measures should be investigated.

In Cameroon, Telfairia occidentalis is often cultivated during the onset of the rainy season between the months of March and April but there is paucity of information on the management strategies of leaf spot disease of Telfairia occidentalis. Though some studies have been carried out by [4] there is still need to 
investigate other cultural techniques in order to ascertain the most efficient and effective leaf spot management strategy. Information on these cultural strategies and tactics on the management of Telfairia occidentalis is craving. In order to close this gap and improve on the quality of the leafy vegetable produced, there is need to investigate other cultural control strategies.

The experiment was conducted to investigate the influence of tillage systems, sowing date and removal of diseased leaves on the incidence and severity of leaf spot disease of Telfairia occidentalis.

\section{Materials and Methods}

\subsection{Location of Study Site}

The study was conducted in the Dschang in 2019 and 2020 cropping seasons beginning in March of each year. Dschang is the headquarters of the Menoua Division which lies on latitude $5^{\circ} 26^{\prime} 38^{\prime \prime} \mathrm{N}$ and longitude $10^{\circ} 03^{\prime} 11^{\prime \prime} \mathrm{E}$. with an equatorial monsoon climate. Menoua Division is one of the eight Divisions in the West Region of the Republic of Cameroon. The Division constitutes one of the main crop-producing areas in the Western Highlands agro-ecological zone of Cameroon. This region is known to carry out intensive crop farming even though the fertility of the soil is constraint [11]. Telfairia occidentalis is cultivated in this region by some individuals who have recognized the nutritional and health preeminence of the leafy vegetable. Dschang is characterized by an average annual temperature of $20.4^{\circ} \mathrm{C}$, high annual relative humidity of $83 \%$ and a mean annual rainfall of $1936 \mathrm{~mm}$ [12]. The wettest month is September with an average of $244.6 \mathrm{~mm}$ of rain. The locality has two main seasons, the dry and rainy seasons. The dry season begins late into November and ends with the coming of the rains in mid-March. June is the hottest month with an average temperature of $21^{\circ} \mathrm{C}$ and the coldest is July at $18^{\circ} \mathrm{C}$ [11] (Figure 1).

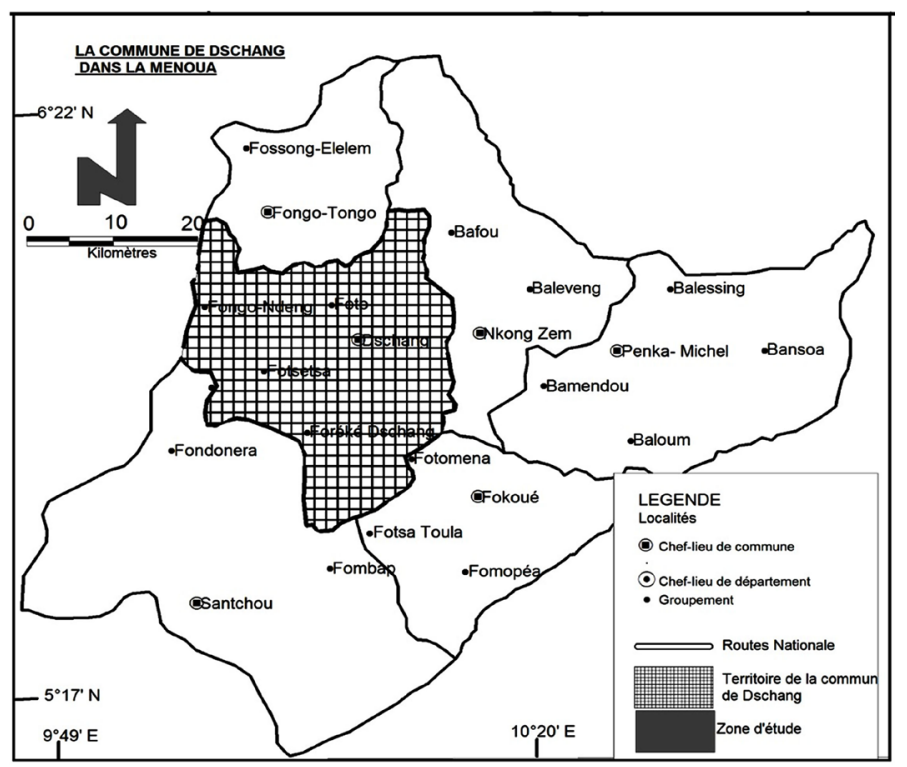

Figure 1. Map of study site, Dschang. (Source: [12]). 


\subsection{Experimental Design}

The experiment was laid out in a Randomized Complete Block Design (RCBD) with three blocks; each with twelve experimental units (Figure 2). Each block had three plots with identical sowing dates. The experiment was laid out over a surface area of $121 \mathrm{~m}^{2}(11 \mathrm{~m} \times 11 \mathrm{~m})$. Each experimental unit measured $1.5 \mathrm{~m} \times$ $1.5 \mathrm{~m}$. Plots and blocks were separated by an alley of $0.4 \mathrm{~m}$.

\subsection{Land Preparation and Establishment of the Crop}

For each cropping season, the field was cleared and debris removed. The experimental units were then measured, pegged and moulded before selected matured, healthy Telfairia occidentalis seeds were sowed. All experimental units were identified with unique tags.

Seeds were sown by broadcasting. Four (4) seeds were sown at the depth of 3 $\mathrm{cm}$ on each plot and at the rate of $1 \mathrm{~m} \times 1 \mathrm{~m}$. At the untilled site, a small slit or
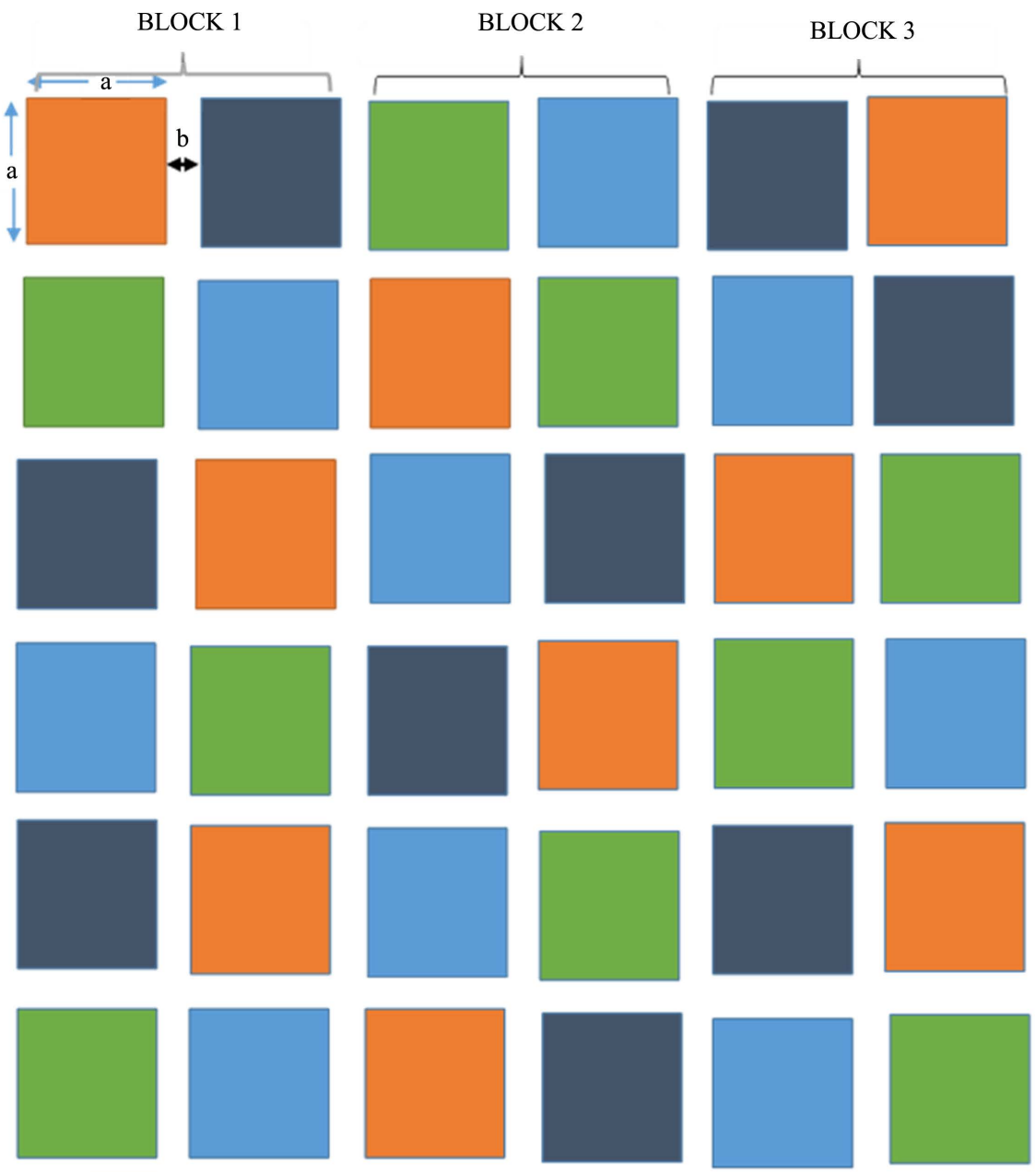

$\mathrm{SD}_{1} \quad$ Sowing Date 1

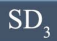

Sowing Date 3

$\mathrm{a}=1.5 \mathrm{~m}$

$\mathrm{SD}_{2}$

Sowing Date 2

Sowing Date 4

$\mathrm{a}=0.4 \mathrm{~m}$

Figure 2. Experimental design. 
punching a hole was opened into the soil with the aid of a machete before sowing while at the tilled site, hands were directly used to open the hole and the seeds sown. Four sowing dates were chosen at an interval of seven (7) days on the selected plots ( 3 plots per replicate) and at the end of the four weeks sowing period a total of 36 plots had been sown with a total of 144 seeds. First sowing was on the last week of March of each year, second and third sowing were on the first and second weeks of April while fourth sowing was on the third week of April of each year.

Staking, to enable the plants grow upwards, was carried out three weeks after emergence (WAE) and weed removal was carried out at regular intervals to ensure sustainability of the crop in the field. Bamboo trellises at a height of $1 \mathrm{~m}$ were constructed over each experimental unit on which the vigorous herbaceous stems will support themselves. Other field activities aimed at ensuring the sustainability of the crop on the field and preventing intrusion by domestic animals were as well executed for better assessment of the leaf spot disease and growth of the crop.

\subsection{Data Collection}

\subsubsection{Disease Assessment on the Experimental Plots}

Data collection for disease incidence was carried out fourfold, following the appearance of the disease symptoms in the field beginning three WAE. The total number of leaves for each stand was counted and leaves showing disease symptoms of leaf spot on all the plants per plot were cautiously removed. To reduce the source of inoculum, the disease incidence and severity was therefore monitored by the removal of the infected leaves on each plant.

\subsubsection{Calculations for Disease Incidence}

The data for disease incidence (DI) was arrived at by calculating the percentage of the proportion of leaves infected per plant and per plot with the speculated period using the following formula:

$$
\text { Percentage DI }=\frac{\text { Number of leaves infected }}{\text { Total number of leaves sampled }} \times 100
$$

\subsubsection{Determination of Disease Severity}

The disease severity commenced immediately after the assessment of the disease incidence and different treatments were same as for disease incidence. The formula for leaf spot disease severity (DS) is given by:

$$
\% \mathrm{DS}=\frac{\text { Area of leaf tissue infected }}{\text { Total area of leaf sampled }} \times 100
$$

Due to the cumbersome nature of the equation above, the disease severity was assessed based on the percentage disease incidence (proportion of diseased leaves per plant) following the modified disease severity scale of [13] as follows (Table 1): 
Table 1. Disease severity scale of leaf spot (scored at weekly interval).

\begin{tabular}{|c|c|c|}
\hline $\begin{array}{l}\text { Severity } \\
\text { Scale }\end{array}$ & $\begin{array}{l}\text { Numerical } \\
\text { Rating }\end{array}$ & Description of symptom \\
\hline 0 & 0 & No disease. \\
\hline $1-20$ & 1 & Infection of the leaves with small spot lesions. \\
\hline $21-40$ & 2 & $\begin{array}{l}\text { Moderate infection of leaf spot lesions spreading on the surface } \\
\text { of the leaves. }\end{array}$ \\
\hline $41-60$ & 3 & $\begin{array}{l}\text { Severe infection of the leaves with leave spot lesions almost found } \\
\text { in all the leaflets. }\end{array}$ \\
\hline $61-80$ & 4 & $\begin{array}{l}\text { Very severe infection on all the leaves with spot lesions spreading } \\
\text { in all the leaflets and coalescing. }\end{array}$ \\
\hline $81-100$ & 5 & $\begin{array}{l}\text { The entire plant are completely infected with all leaves having leaf } \\
\text { spot disease, some of the leaves having holes and there is leaf tearing. }\end{array}$ \\
\hline
\end{tabular}

\subsection{Statistical Analysis}

All data collected were input into Microsoft Excel for calculations involving leaf spot disease incidence and disease severity and the data was analyzed using the statistical package for social sciences (SPSS) version 23. An analysis of variance (ANOVA) was carried out and the means separated using Duncan Multiple Range Test (DMRT) for statistical significance at 95\% confidence interval ( $\mathrm{p} \geq$ 0.05).

Pearson correlation analysis was used to determine the relationship between leaf spot disease incidence and severity.

\section{Results and Discussion}

\subsection{Results}

\subsubsection{Leaf Spot Disease Incidence and Severity at Sowing Dates}

In spite of the tillage system and cropping season, the leaf spot disease incidence of Telfairia occidentalis leaves witnessed a steady decrease from sowing date one $(19.137 \pm 12.206)$ to sowing date three $(16.652 \pm 10.662)$, with a very low incidence. Disease incidence then increased precipitously from sowing date three to four (Figure 3). Statistical analysis showed that there was no significant difference amongst sowing dates one, two and three. A significant difference was however documented between sowing date four and sowing dates one, two and three (Table 2).

In the first year of the study, leaf spot disease incidence was generally higher compared to that of the second across all sowing dates (Figure 4). A very high disease incidence was observed at sowing date four $(28.02 \pm 15.097)$ while sowing date two recorded a comparatively lower disease incidence $(20.285 \pm 12.466)$ in 2019. On the contrary, very low disease incidences were recorded in 2020 across all sowing dates. A very low disease incidence was recorded at sowing date three $(21.245 \pm 10.839)$ while sowing date four registered a very high disease incidence $(16.813 \pm 12.269)$ in the same year (Table 3$)$. 


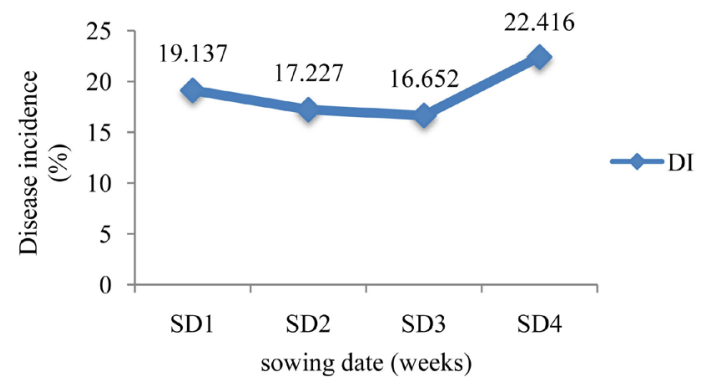

Figure 3. Variation of leaf spot disease incidence at sowing dates.

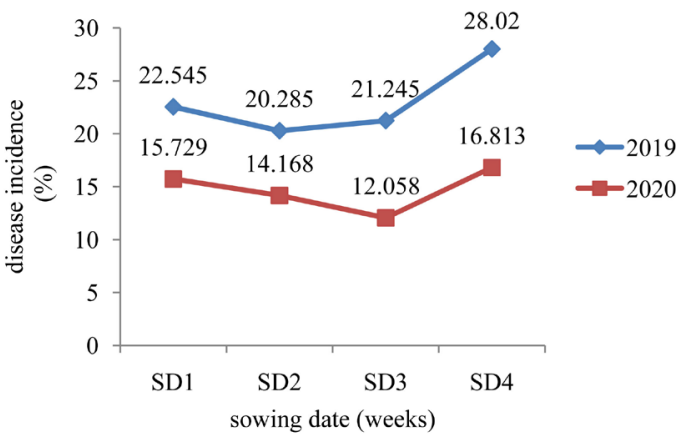

Figure 4. Variation of disease incidence at cropping seasons based on sowing dates.

Table 2. Disease incidence at sowing dates.

\begin{tabular}{cc}
\hline Sowing date $(\mathrm{SD})$ & Disease incidence \\
\hline $\mathrm{SD}_{4}$ & $22.416 \pm 14.816^{\mathrm{a}}$ \\
$\mathrm{SD}_{1}$ & $19.137 \pm 12.206^{\mathrm{b}}$ \\
$\mathrm{SD}_{2}$ & $17.227 \pm 11.73^{\mathrm{b}}$ \\
$\mathrm{SD}_{3}$ & $16.652 \pm 10.662^{\mathrm{b}}$ \\
\hline
\end{tabular}

a,b; Means in the same column followed by the same superscript are not significantly different at $\mathrm{p} \leq 0.05$ (DMRT).

Table 3. Disease incidence at cropping seasons based on sowing dates.

\begin{tabular}{ccc}
\hline Sowing date & Cropping season & Disease incidence \\
\hline $\mathrm{SD}_{1}$ & 2019 & $22.545 \pm 11.795$ \\
& 2020 & $15.729 \pm 11.723$ \\
$\mathrm{SD}_{2}$ & 2019 & $20.285 \pm 12.466$ \\
& 2020 & $14.168 \pm 10.155$ \\
$\mathrm{SD}_{3}$ & 2019 & $21.245 \pm 10.839$ \\
& 2020 & $12.058 \pm 8.288$ \\
$\mathrm{SD}_{4}$ & 2019 & $28.02 \pm 15.097$ \\
& 2020 & $16.813 \pm 12.269$ \\
\hline
\end{tabular}

Considering disease severity within this study, there was a reduction in leaf spot disease severity from sowing date one $(1.535 \pm 1.847)$ to two $(1.257 \pm$ 0.697); and a steady increase from sowing date two through sowing dates three 
and four (Figure 5).

Sowing date four recorded the highest disease severity $(1.611 \pm 0.73)$ compared to sowing date two and three which was significant but comparable to sowing date one. The lowest disease severity $(1.257 \pm 0.697)$ was documented at sowing date two compared to sowing date one and four but comparable to sowing date three (Table 4).

In the first year of this study, leaf spot disease severity was generally higher compared to that of the second year across all sowing dates (Figure 6). A very high disease severity $(1.889 \pm 0.723)$ was documented at sowing date four while sowing date two recorded a comparatively lower disease severity $(1.389 \pm 0.761)$ in 2019. In contrast, very low disease severities were recorded in 2020 across all sowing dates. Identical disease severities were evident at sowing dates two and three while the highest disease severity $(1.333 \pm 0.628)$ was documented at sowing date four in the second year (Table 5).

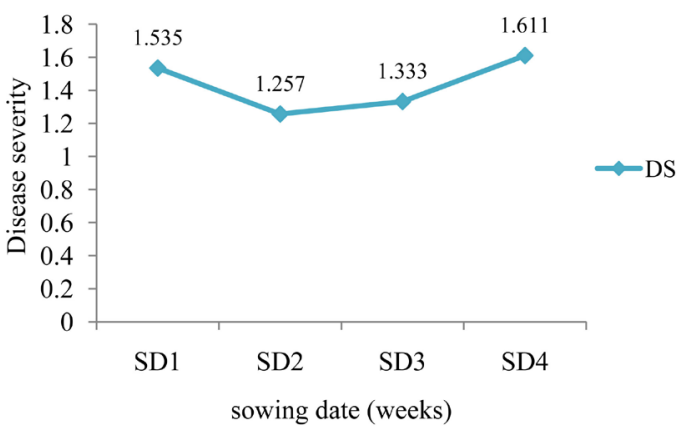

Figure 5. Variation of disease severity at sowing date.

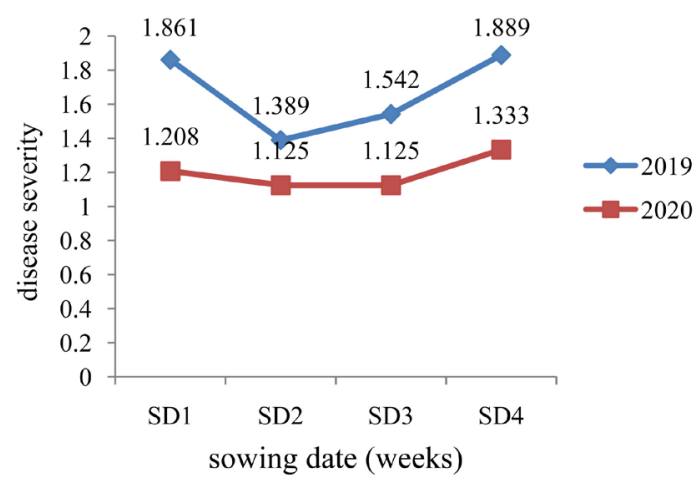

Figure 6. Variation of disease severity at cropping seasons based on sowing date.

Table 4. Disease severity at sowing dates.

\begin{tabular}{cc}
\hline Sowing date $(\mathrm{SD})$ & Disease severity \\
\hline $\mathrm{SD}_{2}$ & $1.257 \pm 0.697^{\mathrm{a}}$ \\
$\mathrm{SD}_{3}$ & $1.333 \pm 0.515^{\mathrm{ab}}$ \\
$\mathrm{SD}_{1}$ & $1.535 \pm 1.847^{\mathrm{bc}}$ \\
$\mathrm{SD}_{4}$ & $1.611 \pm 0.730^{\mathrm{c}}$ \\
\hline
\end{tabular}

a,b,c Means in the same column followed by the same superscript are not significantly different at $\mathrm{p} \leq 0.05$ (DMRT). 
Table 5. Disease severity at cropping seasons based on sowing date.

\begin{tabular}{ccc}
\hline Sowing date & Cropping season & Disease severity \\
\hline $\mathrm{SD}_{1}$ & 2019 & $1.861 \pm 2.491$ \\
& 2020 & $1.208 \pm 0.670$ \\
$\mathrm{SD}_{2}$ & 2019 & $1.389 \pm 0.761$ \\
& 2020 & $1.125 \pm 0.604$ \\
$\mathrm{SD}_{3}$ & 2019 & $1.541 \pm 0.555$ \\
& 2020 & $1.125 \pm 0.373$ \\
$\mathrm{SD}_{4}$ & 2019 & $1.889 \pm 0.723$ \\
& 2020 & $1.333 \pm 0.628$ \\
\hline
\end{tabular}

\subsubsection{Leaf Spot Disease Incidence and Severity at Tillage Systems}

Sowing dates and cropping seasons notwithstanding, no-till plots recorded a higher leaf spot disease incidence $(19.657 \pm 11.532)$ compared to the till plots (Figure 7). The numerical superiority for the no-till unit was however not significant at $\mathrm{p} \leq 0.05$ (Table 5).

Disease incidence at tillage systems based on sowing date within this study period revealed that the no-tillage unit recorded higher leaf spot disease incidences at sowing dates one and two. Sowing dates three and four registered comparatively lower incidences compared to the till unit at the same sowing dates (Figure 8). A higher disease incidence was documented at the till unit at the fourth sowing date $(22.464 \pm 16.718)$ while a lower incidence was observed at the same tillage system but at the second sowing date $(13.631 \pm 11.978)$. The no-till unit registered a very low disease severity at sowing date three $(15.803 \pm 9.154)$ and a very high disease incidence at sowing date four (22.368 \pm 12.752$)$ (Table 6).

As regards disease severity, the no-till unit registered a slightly higher value for leaf spot disease severity compared to the till unit (Table 7) but the numerical supremacy of this value was not significant at $\mathrm{p} \leq 0.05$.

Disease severity at tillage systems based on sowing date within cropping seasons disclosed disease severities were higher at the no-till unit for sowing dates one and two and lower for sowing dates three and four compared to the till units at the same sowing dates (Table 8, Figure 9). Very low leaf spot disease severity was noted down at sowing date three $(1.222 \pm 0.451)$ for the no-till unit while sowing date one displayed a very high disease severity $(1.736 \pm 2.518)$ for the same tillage system and for both tillage systems. A very low leaf spot disease severity was documented at sowing date two $(1.047 \pm 0.740)$ for the till unit while sowing date four recorded a very high disease severity $(1.625 \pm 0.862)$ for the same tillage system (Table 9).

\subsubsection{Leaf Spot Disease Incidence and Severity at Cropping Seasons}

Disease incidence was higher in the first year of this study compared to the second regardless of the tillage system and sowing date (Figure 10). In the first cropping season of this study, a high leaf spot disease incidence (23.024 \pm 12.935$)$ 


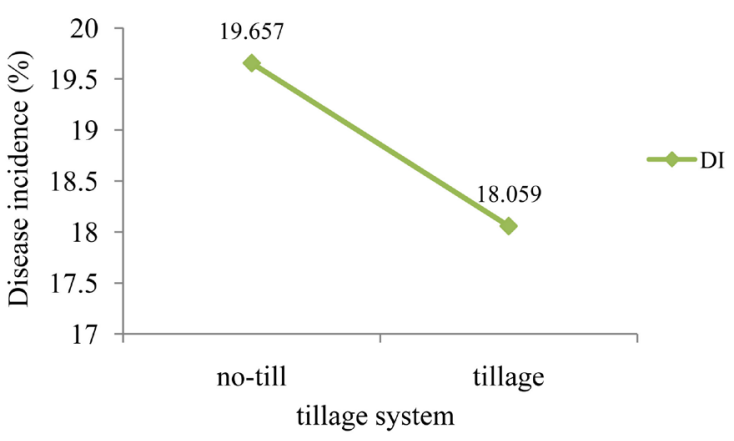

Figure 7. Variation of disease incidence in tillage systems.

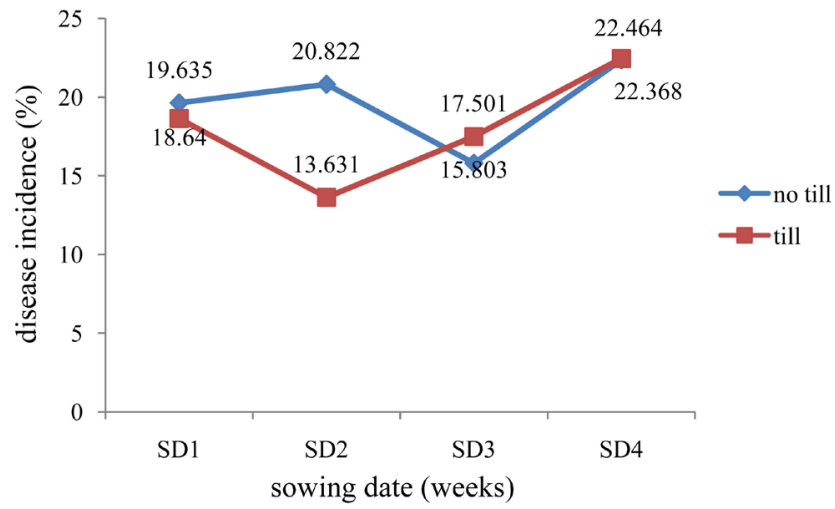

Figure 8. Variation of disease incidence at tillage systems based sowing dates.

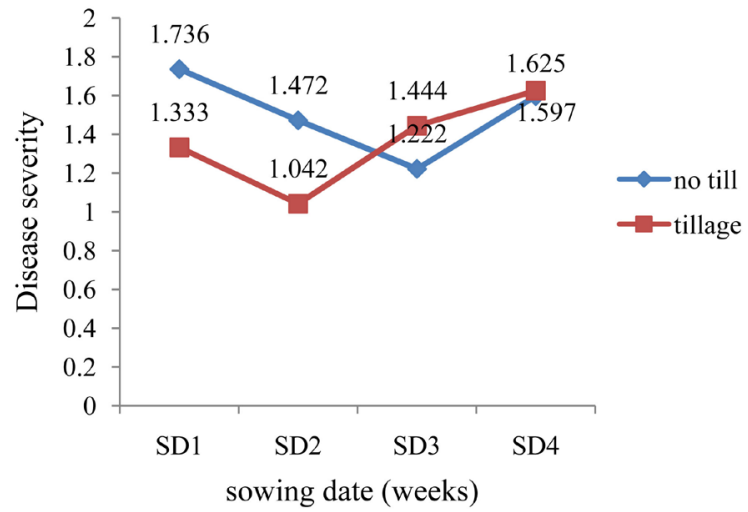

Figure 9. Variation of disease severity at tillage systems based sowing date.

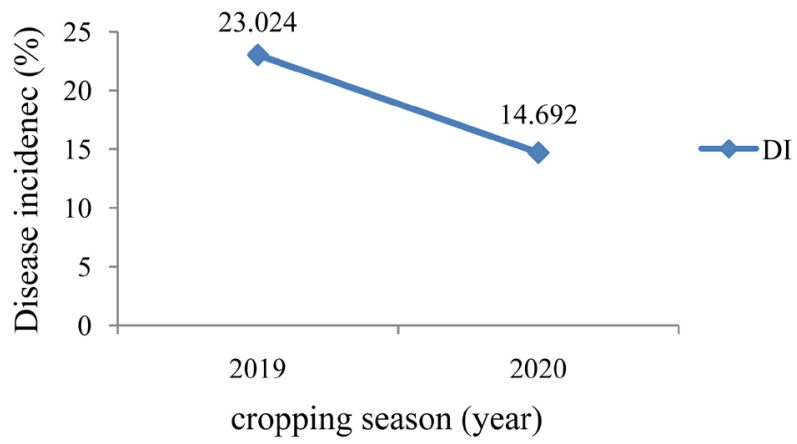

Figure 10. Variation of disease incidence at cropping seasons. 
Table 6. Disease incidence at tillage systems.

\begin{tabular}{cc}
\hline Tillage system & Disease incidence \\
\hline No-till & $19.657 \pm 11.532^{\mathrm{a}}$ \\
Till & $18.059 \pm 13.594^{\mathrm{a}}$ \\
\hline
\end{tabular}

${ }^{a}$ Means in the same column followed by the same superscript are not significantly different at $p \leq 0.05$ (DMRT).

Table 7. Disease incidence at tillage systems based on sowing dates.

\begin{tabular}{ccc}
\hline Sowing date & Tillage system & Disease incidence \\
\hline $\mathrm{SD}_{1}$ & Till & $18.640 \pm 11.841$ \\
& No-till & $19.635 \pm 12.624$ \\
$\mathrm{SD}_{2}$ & Till & $13.631 \pm 11.978$ \\
& No-till & $20.822 \pm 10.383$ \\
$\mathrm{SD}_{3}$ & Till & $17.50 \pm 11.987$ \\
& No-till & $15.803 \pm 9.155$ \\
$\mathrm{SD}_{4}$ & Till & $22.464 \pm 16.718$ \\
& No-till & $22.368 \pm 12.753$ \\
\hline
\end{tabular}

Table 8. Disease severity at tillage systems.

\begin{tabular}{cc}
\hline Tillage system & Disease severity \\
\hline No-till & $1.507 \pm 1.349^{\mathrm{a}}$ \\
Till & $1.361 \pm 0.743^{\mathrm{a}}$ \\
\hline
\end{tabular}

${ }^{\mathrm{a}}$ Values in a column followed by the same letters are not significantly different at $\mathrm{p} \leq 0.05$ (DMRT).

Table 9. Disease severity at tillage systems based on sowing dates.

\begin{tabular}{ccc}
\hline Sowing date & Tillage system & Disease severity \\
\hline $\mathrm{SD}_{1}$ & Till & $1.333 \pm 0.671$ \\
& No-till & $1.736 \pm 2.518$ \\
$\mathrm{SD}_{2}$ & Till & $1.047 \pm 0.740$ \\
& No-till & $1.472 \pm 0.581$ \\
$\mathrm{SD}_{3}$ & Till & $1.444 \pm 0.554$ \\
& No-till & $1.222 \pm 0.451$ \\
$\mathrm{SD}_{4}$ & Till & $1.625 \pm 0.862$ \\
& No-till & $1.60 \pm 0.573$
\end{tabular}

was documented compared to that observed in the second $(14.692 \pm 10.814)$. Statistical analysis revealed that the values were significant at $\mathrm{p} \leq 0.05$ (Table 7).

Regarding disease incidence within this study period at tillage systems, there was most often than not a drop in disease incidence from the first to the second 
cropping season (Figure 11). Generally, there was a trivial drop in disease incidence from 2019 to 2020 seasons at the no-till unit while there was a sharp fall from the first season to the second for the tilled plots The till unit registered a higher leaf spot disease incidence $(25.782 \pm 13.856)$ in 2019 compared to no-till unit for the same cropping season. In the second year of the study, the till unit revealed a tremendously lower disease incidence $(10.336 \pm 7.671)$ compared to that observed in the first cropping season (Table 10).

Regardless of the tillage system and sowing date, there was a drop in disease severity from the first to the second cropping season (Table 11, Figure 12). Though disease severity was largely characterized by the infection of leaves with small spot lesions regardless of the tillage system and sowing date, the 2019 cropping season recorded a higher disease severity $(1.67 \pm 1.389)$ compared to 2020 which was significant (Table 9).

Regarding disease severity at cropping seasons and tillage systems notwithstanding the sowing dates, there was a decline in severity from 2019 to 2020 (Table 12, Figure 13). The till unit recorded a higher leaf spot disease severity $(1.722 \pm 0.806)$ in the first year of the study while the disease severity was comparatively lower $(1.618 \pm 1.794)$ at the no-till unit for the same year. In the second

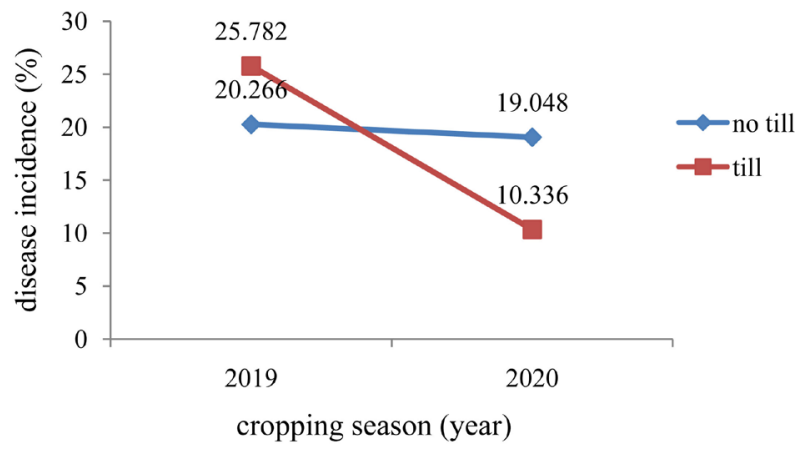

Figure 11. Disease incidence at cropping seasons based on tillage systems.

Table 10. Disease incidence at cropping seasons.

\begin{tabular}{cc}
\hline Cropping season & Disease incidence \\
\hline 2019 & $23.024 \pm 12.935^{\mathrm{a}}$ \\
2020 & $14.692 \pm 10.814^{\mathrm{b}}$ \\
\hline
\end{tabular}

${ }^{a, b}$ Means in the same column followed by the same superscript are not significantly different at $p \leq 0.05$ (DMRT).

Table 11. Disease incidence at cropping seasons based on tillage systems.

\begin{tabular}{ccc}
\hline Cropping season & Tillage system & Disease incidence \\
\hline \multirow{2}{*}{2019} & Till & $25.782 \pm 13.855$ \\
& No-till & $20.266 \pm 11.335$ \\
2020 & Till & $10.336 \pm 7.671$ \\
& No-till & $19.048 \pm 11.733$ \\
\hline
\end{tabular}




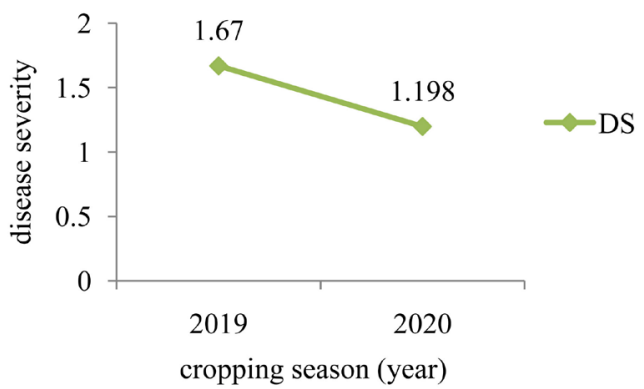

Figure 12. Disease severity at cropping seasons.

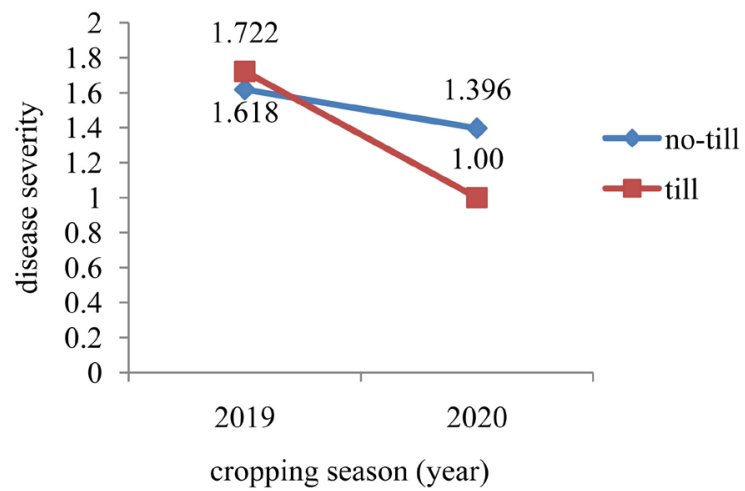

Figure 13. Variation of disease severity at cropping seasons based on tillage systems.

Table 12. Disease severity at cropping seasons based on tillage systems.

\begin{tabular}{ccc}
\hline Cropping season & Tillage system & Disease severity \\
\hline \multirow{2}{*}{2019} & Till & $1.722 \pm 0.806$ \\
& No-till & $1.618 \pm 1.794$ \\
2020 & Till & $1.00 \pm 0.443$ \\
& No-till & $1.396 \pm 0.639$ \\
\hline
\end{tabular}

year of the investigation, the till unit registered lower disease severity $(1.00 \pm$ 0.443) compared to the no-till unit (Table 13).

\subsubsection{Correlation between Disease Incidence and Disease Severity}

Pearson correlation analysis revealed that there was a highly positive correlation $(\mathrm{p}<0.01)$ between the leaf spot disease incidence and disease severity which was statistically significant at $\alpha=0.01$. Thus as disease incidence increased, so too was disease severity. The coefficient of determination indicates that $56 \%$ of the variation on the disease incidence could be accounted for on the basis of variability on the disease severity (or vice versa). Although it is apparent that disease incidence caused disease severity, there is also the likelihood that one or more extraneous variables which are related to disease incidence and/or disease severity, which have not been taken into account in the analysis, could be the unfeigned reason for the moderate relationship that was ascertained between the two variables (Table 14). 
Table 13. Disease severity at cropping seasons.

\begin{tabular}{cc}
\hline Cropping season & Disease severity \\
\hline 2019 & $1.670 \pm 1.389^{\mathrm{a}}$ \\
2020 & $1.198 \pm 0.584^{\mathrm{b}}$ \\
\hline
\end{tabular}

${ }^{a, b}$ Means in the same column followed by the same superscript are not significantly different at $p \leq 0.05$ (DMRT).

Table 14. Pearson correlation for disease incidence and disease severity.

\begin{tabular}{cccc}
\hline & & DI & DS \\
\hline \multirow{4}{*}{ DI $\quad$ Pearson Correlation } & 1 & $0.560^{* *}$ \\
Sig. (2-tailed) & & 0.000 \\
& Sum of Squares and Cross-products & $91,576.208$ & 4432.933 \\
Covariance & 159.263 & 7.709 \\
$\mathrm{~N}$ & 576 & 576 \\
Pearson Correlation & $0.560^{* *}$ & 1 \\
Sig. (2-tailed) & 0.000 & 683.493 \\
& Sum of Squares and Cross-products & 4432.933 & 1.189 \\
Covariance & 7.709 & 576 \\
\hline
\end{tabular}

${ }^{*}$ Correlation is significant at the 0.01 level $(\mathrm{p}<0.01)$.

\subsection{Discussion}

Telfairia occidentalis leaf spot disease incidence and severity was observed to be lower and not significant following statistical analysis at sowing dates two and three across the tillage systems and within the period of investigation. These sowing dates (first and second weeks of April) could not have coincided with the susceptible stage of the leafy vegetable resulting to reduced infection. This could be attributed to lower initial inoculum level following removal of diseased leaves every fortnight and luxuriant vegetative growth despite the high rains and humidity. These results are in consonance with [7] who reported that removal of diseased leaves every fortnight in Telfairia occidentalis intercropped with other crops had the effect of considerably reducing leaf spot diseased incidence and severity.

A very high leaf spot disease incidence and severity was recorded at sowing date one compared to sowing dates two and three. These results are in accord with earlier investigations reported by [14] who intimated that higher incidences and severities of scab were recorded on the early sown cowpeas than later sown crops. This could be ascribed to changes in the microclimate of the environment remarkably rainfall and high humidity coupled with susceptible stage of the crop which favoured rapid germination and multiplication of the fungus following the transition from dry season to rainy season. The rapid vegetative growth and removal of diseased leaves could not however reduce the disease incidence and 
severity as the crop was more vulnerable to infection.

The very high disease incidence and severity in numerical terms and statistical significance observed in sowing date four could be due to relatively high inoculum built up from sowing dates one, two and three coupled with much reduced vegetative growth which resulted in fewer leaves being produced. As the leaves aged, they became more susceptible to infection by Phoma sorghina. With fewer leaves, new infections were inescapable despite removal of diseased leaves.

Leaf spot disease incidence and severity, was not statistically significant on tilled and no-till plots. This could be attributed to the fact that Phoma sorghina is essentially a wind borne pathogen. [7] reported that the pathogens responsible for Telfairia occidentalis leaf spot were wind borne. It appeared that vegetative growth of Telfairia occidentalis was virtually indistinguishable in tilled and untilled units. This is consistent with [15] who reported that Telfairia occidentalis planted on no tilled plots were competing in terms of growth rate with those on mound tilled plots. Tillage creates an environment more favourable for growth in vigour which conferred some resistance to new and rapid infections. [16] reported that no-tillage safeguards soil health. With zero tillage, soil moisture content and temperature is conserved coupled with increased efficiency in natural cycles in no-till soils. This could have provided optimal conditions for growth of the crop in the field which possibly minimized disease incidence and severity. There was however pressure from weeds at the no-till unit. Another report however gave contrary results from this and earlier studies. [17] highlighted that significant differences were recorded in growth and yield parameters in Telfairia occidentalis cultivated on till and no-till plots in an utisol.

Disease severity was generally characterized by infection of leaves with small spot lesions. This could be attributed to the fact that diseased leaves were removed every fortnight, minimizing the tendency of infection becoming moderate, severe, and very severe or for the stands to be completely infected. This is in agreement with [7] who intimated that removal of diseased leaves in Telfairia occidentalis every fortnight had the effect of considerably reducing leaf spot disease incidence and severity. Disease severity was shown to be very severe in plots where diseased leaves were not removed. It was reasoned that, the cultural practice of removal of diseased leaves at regular intervals significantly reduced initial inoculum levels which certainly retarded the spread of new infections. As such, infection was characterized only by small spot lesions.

The high leaf spot disease incidence observed in 2019 compared to 2020 could be due to climate variability which favoured the development and spread of the disease on the field. [18] reported that increase in temperatures generally increases rates of fungal growth and reproduction and extends the reproductive period resulting in more generations within a given time frame. Furthermore, [9] reported that climatic changes are known to affect pathogen development and survival rates with possible modification of host susceptibility that could lead to changes in the impact of diseases on food crops. The authors went further to highlight that climate change may affect not only the optimal conditions 
for infection but also host specificity and mechanisms of plant infection. In addition, [19] intimated that climate influences the incidence as well as temporal and spatial distribution of plant diseases. Phoma sorghina is a necrotrophic pathogen which obtains nutrients from living cells of Telfairia occidentalis leaves and maintains a lengthy and deep interaction with their host. Therefore, all climatic factors that cause or accelerate tissue death, such as high temperatures, could favour high leaf spot disease incidence and severity as was the case in 2019.

\section{Conclusion}

For very low leaf spot disease incidence and severity, sowing dates two and three coupled with removal of diseased leaves every fortnight regardless of the tillage system turned out to be better. These cultural strategies and tactics can therefore be embraced by cultivators to enhanced large scale and quality (healthy) production of Telfairia occidentalis leaves. Low input technologies of this sort are affordable to poor cultivators and vital for self-sufficiency in the production of quality Telfairia occidentalis leaves.

\section{Acknowledgements}

This article is part of a Ph.D. thesis submitted by the first author. Immense thanks to the authorities of the Faculty of Agronomy and Agricultural Sciences (FASA), Dschang, University of Dschang for the arable land accorded me to realize this piece of scientific investigation.

\section{Conflicts of Interest}

The authors declare no conflicts of interest regarding the publication of this paper.

\section{References}

[1] Nwonuala, A. and Obiefuna, J. (2015) Yield and Yield Components of Fluted Pumpkin (Telfairia occidentalis). International Journal of Agriculture Innovations and Research, 4, 421

[2] Orole, R.T., Orole, O.O., Aisoni, J.E., Isyaku, J. and Mohammed, Y.S. (2020) Comparative Study of the Physicochemical Properties of Male and Female Fluted Pumpkin (Telfairia occidentalis). The Journal of Medical Research, 6, 55-61.

[3] Odiaka, N.I. and Schippers, R.R. (2004) Telfairia occidentalis Hook f. [Internet] Record from PROTA4U. Grubben, G.J.H. and Denton, O.A. (Editors), PROTA (Plant Resources of Tropical Africa).

[4] Annih, M.G., Tatiana, N.C.B., Kinge, T.R., Mariette, A. and Kebei, A.K. (2020) Effect of Animal Manure on the Incidence and Severity of Leaf Spot Disease of Fluted Pumpkin (Telfairia occidentalis) in Dschang, West Region of Cameroon. American Journal of Plant Sciences, 11, 1057-1076. https://doi.org/10.4236/ajps.2020.117076

[5] Ashely, B., Michelle, M., Ponder and Julia, G. (2018) Phoma Infections: Classification, Potential Food Sources, and Their Clinical Impact. Microorganisms, 6, 58. https://doi.org/10.3390/microorganisms6030058 
[6] Udo, S.E., Osai, E.O., Umana, E.J., Markson, A.A. and Madunagu, B.E. (2013) Infection Related Changes in Nutritional Contents of Fluted Pumpkin (Telfairia occidentalis) Infected by Diplocossum spicatum and Control Using Plant Extracts. International Journal of Research in Applied Natural and Social Sciences, 1, 29-36.

[7] Nwufo, M.I. and Ihejirika, G.O. (2008) Influence of Intercropping and Removal of Diseased Leaves on Incidence and Severity of Leaf Spot Disease of Telfairia occidentalis Hook f. Caused by Phoma sorghina.

[8] Osai, E.O., Udo, S.E., Okoli, C.E. and Bemoh, B.E. (2017) Comparative Efficacy of Three Plant Extracts for the Control of Leaf Spot Disease in Fluted Pumpkin (Telfairia occidentalis Hook F.). Journal of Biology, Agriculture and Health Care, 7, 56-62.

[9] Mbong, A.G., Tembe-Fokunang, E.A., Berinyuy, E.B., Manju, E.B., Ngo, V.N., Mbah, J.A., Galega, T.B.P. and Fokunang, C.N. (2019) An Overview of the Impact of Climate Change on Pathogens, Pest of Crops on Sustainable Food Biosecurity. International Journal of Ecotoxicology and Ecobiology, 4, 114-124. https://doi.org/10.11648/j.ijee.20190404.15

[10] Godwin-Egein, M.I., Okereke, V.C. and Justus, O.P. (2015) Effect of Fluted Pumpkin (Telfairia occidentalis) and Maize (Zea mays) Intercrop on Leaf Spot Disease. American Journal of Agricultural Science, 2, 133-137.

[11] Kome, G.K., Enang, R.K. and Bine, F.K. (2017) Climate Change, Soil Fertility Management and the Nexus: A Knowledge and Opinions Study in Western Cameroon. Journal of Scientific Research \& Reports, 13, 1-16. https://doi.org/10.9734/JSRR/2017/31730

[12] Plan Communal De Développement De Dschang, 2011.

[13] Orji, O.J., Ibeawuchi, I.I. and Obilo, O.P. (2015) Effect of Poultry Manure on Incidence and Severity of Foliar Diseases and Weed of Telfairia occidentalis (ugu) Intercropped with Cassava and Maize. Journal of Biology, Agriculture and Healthcare, 5, 205-211.

[14] Mbong, G.A., Akem, C.N., Labi, O.A., Emechebe, A.M. and Alegbejo, M.D. (2010) Effect of Sowing Date on the Incidence, Apparent Infection Rate and Severity of Scab on Cowpea. Asian Journal of Agricultural Sciences, 2, 63-68.

[15] Okeke, C.G., Oluka, S.I. and Oduma, O. (2016) Effect of Tillage and Staking on the Production of Fluted Pumpkin. American Journal of Engineering Research, 5, 54-56.

[16] Peigne, J., Ball, B.C., Roger-Estrade, J. and David, C. (2006) Is Conservation Tillage Suitable for Organic Farming? A Review. Soil Use and Management, 23, 129-144. https://doi.org/10.1111/j.1475-2743.2006.00082.x

[17] Edna, A.A. and Ime, O.U. (2017) Evaluation of Different Tillage Practices on Growth and Yield of Fluted Pumpkin, Telfairia occidentalis in Uyo, Southeastern Nigeria. International Journal of Sustainable Agricultural Research, 4, 45-49. https://doi.org/10.18488/journal.70.2017.42.45.49

[18] Marine, G.L.G., Martin, J.B., Ming, P.Y. and Roger, A.C. (2016) Effect of Temperature on Disease Severity in Plants of Subterranean Clover Infected Singly or in Mixed Infection with Bean Yellow Mosaic Virus and Kabatiella caulivora. Journal of Phytopathology, 164, 608-619. https://doi.org/10.1111/jph.12484

[19] Yáñez-López, R.I., Torres-Pacheco, R.G., Guevara-González, M.I., Hernández Zul, J.A., Quijano-Carranza and Rico-García, E. (2012) The Effect of Climate Change on Plant Diseases. African Journal of Biotechnology, 11, 2417-2428.

http://www.academicjournals.org/AJB

https://doi.org/10.5897/AJB10.2442 